\title{
The "buy local" challenge to institutional foodservice corporations in historical context
}

\author{
Sarah J. Martin, ${ }^{a}, *$ Balsillie School of International Affairs, University of Waterloo \\ Peter Andrée, ${ }^{\mathrm{b}}$ Department of Political Science, Carleton University
}

\begin{abstract}
Submitted 26 October 2011 / Revised 15 January and 8 March 2012 / Accepted 29 March 2012 / Published online 3 June 2012
Citation: Martin, S. J., \& Andrée, P. (2012). The "buy local" challenge to institutional foodservice corporations

in historical context. Journal of Agriculture, Food Systems, and Community Development, 2(3), 161-175.

http://dx.doi.org/10.5304/jafscd.2012.023.008

Copyright (C) 2012 by New Leaf Associates, Inc.
\end{abstract}

\begin{abstract}
Public institutions such as universities and hospitals are being increasingly encouraged by social movements to direct their substantial foodservice budgets toward supporting local farmers and producers. This paper examines a key obstacle to the buy local challenge: the transnational corporations who are contracted by many public institutions in North America to provide foodservices. The institutional food sector is dominated by three large transnational foodservice corporations: Compass Group, ARAMARK, and Sodexo. It is their centralized supply chains and management structures, along with a dependence on prepared and "ready to eat" food, that are barriers to local

\footnotetext{
a, * Corresponding author: Sarah J. Martin, PhD candidate, Balsillie School of International Affairs, University of Waterloo, 67 Erb Street West, Waterloo, Ontario N2L 6C2

Canada; smartin@balsillieschool.ca

b Peter Andrée, Associate Professor, Department of Political

Science, Carleton University, Ottawa, Ontario Canada.

Note: The authors would like to thank the anonymous reviewers who strengthened the article through their thoughtful critique and helpful suggestions.
}

food procurement. Up to this point, there has been little scholarly attention to the origin and organization of these corporations.

This paper's examination of the history and political economy of the institutional foodservice industry illustrates a long association between these companies and public-sector goals over the last 70 years. Comparing past public-sector goals to contemporary campaigns directed at institutional foodservice is therefore instructive. We examine three different political economies that have fostered the development of these corporations: the Second World War, the post-war era from 1945 to the 1970s, and the neoliberal era beginning in the 1970s through today. While recognizing that the barriers to local procurement are real, we also argue that the structure and competitive dynamics of these corporations offer opportunities to make positive changes.

\section{Keywords}

ARAMARK, Compass Group, food value chain, industry opportunity structure, institutional foodservice, local food, political economy, social movements, Sodexo 


\section{Introduction}

Academics, social movement organizations, and food system practitioners are calling for public institutions to support local farmers with their substantial foodservice budgets (e.g. Équiterre, 2010; Sustain UK, 2009, 2012; Vogt \& Kaiser, 2008) and, in turn, to help "scale up" local food systems (e.g. Friedmann, 2007). This shift in resources has the potential to build and strengthen local food distribution infrastructures and support additional new links between local producers, processors, and consumers (Andrée, Dibden, Higgins, \& Cocklin, 2010; Goodman, 2003; Renting, Marsden, \& Banks, 2003). This paper examines the challenges — as well as the opportunities - associated with a key obstacle to the shift toward local procurement: the transnational foodservice corporations who operate within most of these public institutions (Sustain UK, 2009).

The institutional food sector in North America is dominated by three large foodservice corporations: Compass Group, ARAMARK and Sodexo. These transnational corporations (TNCs) are part of a surprisingly large foodservice sector. Two of them are among the largest private employers in the world, with Compass ranked eleventh with 428,202 employees and Sodexo ranked as twentysecond with 379,137 employees (Fortune, 2011). Although ARAMARK does not make the ranking, it is also very large, with 254,000 employees (Datamonitor, 2009). Globally, institutional food accounts for $35 \%$ of the total foodservice market, second only to cafés and restaurants at $46 \%$ and more than fast food at 18\% (Datamonitor, 2009). These three corporations are not the only providers of institutional foodservice (for example, some institutions keep foodservice in-house), but they are the largest operators and have a global reach. Their business model is based on centralized supply chains and management structures, with a reliance on prepared and "ready to eat" food, intended to lower procurement and labor costs.

When placed next to the vital and idiosyncratic local food movement - over 2,300 local food projects in Canada alone (Egbers \& Canadian Cooperative Association, 2009), from new cooperatives to farmers' markets — the institutional food sector may appear to be fixed and intransigent. However, there are also opportunities for change based on the very structure of these TNCs and their competitive practices. The political and economic history of the institutional foodservice industry illustrates a long association between these companies and public-sector goals. Just as historical events and campaigns offer constructive comparisons to contemporary social movement campaigns, comparing past public-sector goals to current efforts directed at institutional foodservice provides a helpful comparison.

This paper argues that social movement organizations and food system practitioners can actually leverage the structure of the foodservice industry and create opportunities for change. Drawing on Schurman (2004) and Schurman and Munro's (2009) research on "industry opportunity structures," which identified several aspects of the biotech industry structure that made it particularly vulnerable to social movements' critiques in the 1990s and early 2000s, and applying these concepts to the institutional food service industry, we show how strategic pressure can be applied to support sustainable local food systems. We argue that it is the foodservice industry's structure and location in public institutions such as universities and hospitals that make it especially vulnerable to critique and boycotts, thus opening them to new ways of doing business.

\section{Context and Theory}

The buy local challenge to institutional food is part of a global trend. For example, the University of Toronto used its sustainability policies to mandate a relationship between its foodservice providers, ARAMARK and Chartwells (a subsidiary of Compass Group), and an Ontario-based thirdparty certifier of local and sustainably produced foods called Local Food Plus (LFP). On this basis, the foodservice companies began purchasing local products in volume in 2007 (Friedmann, 2007; Local Food Plus, n.d.). Similar efforts to reconnect local agriculture with institutional food providers have been made in Rome, the U.K., and the U.S. (Bagdonis, Hinrichs, \& Schafft, 2009; Edible Strategies Enterprises, 2007; Izumi, Wright, \& Hamm, 2010; Morgan \& Sonnino, 2007; Seyfang, 
2006). These efforts address a variety of public policy goals, including sustainable agriculture, public health, and the environment. Local food procurement by institutional foodservices would also help to "re-embed" the market (Polanyi, 2001 [1944]; Raynolds, 2000) within social relations and ecological values (Morgan \& Sonnino, 2007; Sonnino, 2007).

With all of the potential benefits of local foods, it is no surprise that social movements are calling for its procurement by large public institutions. However, the companies that hold catering contracts at these institutions, such as the corporations profiled here, appear to be the major roadblock in the realization of these goals (Sustain UK, 2009). This paper seeks to better understand these obstacles, by considering both the history and current operational practices of these corporations. Unfortunately, there is an absence of critical academic research on foodservice practices. Most interest in this sector has addressed business and marketing practices (Mikkelsen, Kristensen, \& Nielsen, 2005; Yigit, Tengilimoglu, Kisa, \& Younis, 2007), or has a dietary and health focus (Dupertuis, Kossovsky, Kyle, Raguso, Genton, \& Pichard, 2003; Edwards, Williams, Hartwell, \& Schafheitle, 2009). As noted above, recent studies discuss how institutional foodservice companies are being challenged by social movements to change the food they sell, but no one has yet explored the origins of institutional food and how these businesses operate.

To understand the challenges and opportunities associated with the structure of institutional food for the local food movement, we draw on two theoretical approaches. To begin, we highlight how changing political and economic structures (i.e., the political economy) have shaped the operation of institutional foodservice over the last 70 years. Second, we look to the emerging literature on "industry opportunity structures" (e.g., Schurman, 2004), and its four factors: inter-firm competitiveness; the nature of the goods sold; corporate cultures; and relationships in the industry's organizational field. This provides a launching point for our analysis of why and how institutional foodservice corporations are responding to current calls for change. Together, these two frameworks help us make sense of past changes while also helping us think strategically about how to encourage further change, this time toward more local and sustainable procurement.

\section{Methods}

Since little academic work has been done in this area, we rely on a variety of sources for this study. For the historical context we draw heavily on primary sources, including newspapers and industry literature from the Second World War, company websites, government records, and an interview with a Canadian labor union researcher conducted in 2007. Secondary sources for this historical research include foodservice trade and business journals, as well as academic papers that trace company histories.

These sources were supplemented by six indepth interviews conducted in 2007 with individuals working in the institutional foodservice industry in three Canadian universities (as approved by Carleton University's Research Ethics Board). The interviewees were two foodservice workers (a cook and a server) with over 25 years' experience, a manager in charge of a large residence foodservice unit, a manager of foodservice procurement, and an associate director who oversaw a university's extensive foodservice operations. Interview questions focused on how foodservice and procurement had changed during their employment and what the informants saw as the barriers to local food procurement. ${ }^{1}$ In addition, one of the authors (Sarah Martin) worked as a cook and chef for 20 years, including at a university. It was through the move from working in positions where she sourced local food to working in a university setting that many of the barriers to local food provision became clear, thereby starting us on this research path.

\section{Historical Analysis}

The next three sections trace the development of today's foodservice companies through three

\footnotetext{
${ }^{1}$ For example: How do you decide what food to buy? How has procurement changed since you first began? How do you make decisions on what suppliers to use? Has this changed since you began?
} 
specific political economies over the last 70 years: The Second World War, the post-war era to the 1970s, and the 1970s to today. This paper then turns to examining contemporary issues associated with this industry in the light of the "buy local" challenge described above.

\section{Industrial Feeding}

During the Second World War, Allied states were confronted with the twin problems of food rationing and retaining efficient workers for the war production machine. As war production became the primary aim, especially for the U.S., war plants became a site for government intervention to maximize workers' production and efficiency. For example, governments employed professional nutritionists to direct the feeding of nutritionally 'vulnerable' industrial workers. In addition, the inclusion of women in the workforce, along with round-the-clock shifts, meant that home-cooked meals could not be relied on to provide nutritionally 'correct' feeding. In order for experts to address these problems (for instance, how to feed 30,000 people at the Douglas aircraft plant in Santa Monica, California, in an efficient and nutritious manner?) a new model of mass feeding was developed. The solution was a program of "industrial feeding" (Goodhart, 1943) which applied the rules of efficient production (sometimes referred to as productivism) with the rules of the new nutritional science (a.k.a. nutritionism, Scrinis, 2008) to workers' feeding to the exclusion of other considerations. In short, industrial feeding scientifically fuelled industrial workers to increase war production. One of industrial feedings' most enthusiastic supporters was Sir Curtis-Bennett, a UK treasury official who published a book on the subject in 1947. He described industrial feeding as part of "the nucleus of a larger system of industrial welfare" where "science and industry could combine profitably... in evolving a more efficient individual" (Curtis-Bennett, 1949, pp. 301-303).

Industrial feeding was promoted at the same time by legislation in the U.S., Britain, Canada, and France during the Second World War and was implemented by government nutritionists working as industrial feeding specialists in the U.S. and Canada. The industrial feeding program was an antidote to the loss of labor, especially from women as they moved out of the homes and into the factories, and to industrial workers' "poor dietary practices" "'Industrial Feeding Held Vital in War," 1944, p. 18). These programs were a panacea to worker-related production issues. The use of "proper feeding installations" was credited with increased production, fewer industrial accidents, improved morale, and cost savings ("Feeding at Plants Cuts Absenteeism," 1944). Finally, these programs were a part of "capitalism's answer to industrial unrest" (Curtis-Bennett, 1949, pp. 256257). For instance, to curb rising labor unrest due to war-time wage freezes, the Office of Price Administration shifted meat distribution from individuals to the in-plant feeding system, and foodservices to subsidize wages ("Roosevelt Plans to Cut Living Cost," 1943).

Outside the United States, Great Britain's government began a policy of industrial feeding as the War Emergency Regulations required workplaces engaged in the war effort, such as government offices, munitions plants, and any employer with over 250 workers, to provide canteens (CurtisBennett, 1949, p. 256). Corporate taxes in the UK were also restructured to support industrial feeding. This encouraged the growth of "big industrial catering firms" that were thought to have the highly specialized expertise needed for industrial feeding (Curtis-Bennett, 1949, pp. 249-250).

Institutional foodservice in France also began during the Second World War as Vichy France began to direct food to workers. Specifically, a tax break was given to business cafeterias as part of a larger labor code under German occupation in 1942 and 1943 (Mériot, 2006, pp. 49-51). In Canada, the Nutrition Service was established in 1941 as part of the Department of Pensions and National Health. The first function of the service was to "study the food facilities in defense industries from a nutritional viewpoint, and to suggest improvements where possible" (Dominion Bureau of Statistics, 1944). The program had priority in accessing rationed foods, equipment, and construction material that was otherwise scarce during wartime (Goodhart \& Pett, 1945, p. 179).

By the end of the war the industrial feeding system was serving seven million workers in the 
United States, and more than half of U.S. plants had been upgraded to "streamlined" or "fast feed" cafeterias ("Reconverted Industry to Continue," 1945). This mass-feeding model was similar to factory lines with plans that detailed how workers should move through the cafeterias for efficient operation. Shortly after the war, the issue of agricultural surpluses emerged as a problem in the U.S., and industrial feeding came to be seen as part of the solution to that too: "The prospect of Government use of the great industrial feeding system, developed during the war, which feeds 7 million workers, [can now become] an avenue for moving unexpected agricultural surpluses" ("U.S. Buying Meat for War Plant Use,” 1945, 25).

All of these resources concentrated on industrial feeding led to the rapid growth of private caterer-run operations, especially in large plants ("Business of Keeping Factory Workers Well Fed Is Booming," 1942; "Reconverted Industry to Continue," 1945). The wartime equipment, nutritionists, and industrial feeding specialists had created a new model of cafeteria service while at the same time subsidizing the development of private firms. Their growth was further accentuated by another cultural shift: snacks. It was during the war years that there was an expansion of betweenmeal snacks on the factory floor, with carts run by these companies bringing coffee, milk, and ice cream directly to the workers ("Business of Keeping Factory Workers Well Fed Is Booming," 1942).

The progenitors for both ARAMARK and Compass benefited from these programs. The two founders of ARAMARK initially met during the Second World War in a Douglas Aircraft plant where they had independent contracts to supply vending machines (ARAMARK, n.d.). Factory Canteens Ltd., which later became Compass Group, was also established during the Second World War in 1941 (Grant, 2001a). Significantly, the story documented through war-time news articles shows that the foodservice corporations of today came into existence through active government, industry, and labor involvement. This model was not simply a product of the market forces of supply and demand. Rather, it helped to fulfill larger state priorities related to the war effort.
The Postwar Era: 1945-1970s

The second era of institutional food emerged within the economic, political, and social contexts of the post-war years. These years, with a strong emphasis on social welfare, proved to be a perfect incubator for the further development of foodservice TNCs. Rising agricultural production combined with increased food processing and foodservices set the foundation for robust growth of these corporations.

As noted, the two founders of ARAMARK, Davre Davidson and William Fishman, met at a Douglas Aircraft plant in California where they each were independently providing vending services for plant workers (ARAMARK, n.d.). After the war, Davidson's company pioneered vending machines in schools and universities (Becker, 1960). Both vending machine operators — known then as automatic retailers — wanted to expand into what they called "manual" foodservices. Soon after merging into the Automatic Retailers of America (ARA) in 1959, they acquired Slater Systems, the largest U.S. foodservice operator and contractor for colleges and universities (Grant, 2001c).

ARA continued moving into new service areas, including nursing homes and magazine distribution companies, and by 1964 it was operating over 750 manual food operations. ARA's monopoly in the vending machine market caught the attention of the Federal Trade Commission (FTC), which ordered it to divest in the market. This would be the first in a series of run-ins with U.S. federal agencies. In the late 1960s, ARA continued its expansion and moved into airline catering, resort management, and laundry services, among others. It was during this time, in 1967, that Factory Canteens in Britain was bought by Grand Metropolitan, a large conglomerate — an indication that consolidation was occurring in the British market as well (Grant, 2001a, 2001b). In France, Sodexho (Societé d'Exploitation Hotelière and today known as Sodexo) began to expand its foodservices from maritime operations to restaurants serving offices, schools, and hospitals (Grant, 2001b).

ARA ran into trouble with the FTC again in 1972 when anticompetition charges were brought 
against it and it was charged with price fixing (Grant, 2001c). The company was again indicted by a grand jury in 1981, this time for bid-rigging in the student transport division (Grant, 2001c). This evidence shows that although ARA was able to consolidate and grow within the U.S. domestic market, and benefited from the industrial expansion and new services like airline catering, it is also clear that federal agencies were active in policing ARA's business practices as part of the post-war era's social contract. In short, active government regulation checked excessive market control with the aim of ensuring fair competition.

\section{Transnational Foodservice Companies in the Neoliberal Era}

The social contract of the post-war years included state intervention in the economy and support for social welfare projects. In contrast, the neoliberal era (roughly the mid-1970s to today) is known as a period during which that state intervention has been "rolled back" and pro-business regulations are "rolled out" (Peck \& Tickell, 2002). In North America, this period produced an "internationalized agri-industrial food economy" (Winson, 1992, p. 109). The service sector in general experienced corporate consolidation and expansion into all corners of the globe through this period, facilitated by the liberalization of regulations, outsourcing, and privatization by governments (Winson, 1992). This section shows how the institutional food sector, in particular, benefited from these changes.

As 1970s national economic projects began to decline and capital was free to move beyond borders (Hobsbawm, 1994), it is possible to trace an unraveling of the regulations, subsidies, and price support that protected domestic markets. This new era led to the restructuring, or what has been termed the "McDonaldization," of labor, which was characterized by low wages and the erosion of organized labor, having the effect of depressing wages overall (Ritzer, 1998). However, as regulations, subsidies, and price supports began to unravel in the United States, Europe, and Canada, agriculture remained the exception. The result was that institutional food operators came to benefit from both shrinking labor costs and statesubsidized agriculture.
The expansion of foodservice began to jump national borders as capital was freed up during the 1970s. For example, ARA expanded into Europe and Canada in the late 1970s. ARA thus became the largest foodservices company in Canada with the purchase of VS Services (ARAMARK, n.d.). New management in the 1980s changed ARA's name to ARAMARK in the 1990s, and the foodservices division in particular began to prosper. Despite ARA's many previous prosecutions by the FTC, ARAMARK was not prosecuted again.

In Britain, the foodservice arm of Grand Metropolitan, a food and spirits company and owner of Factory Canteens, was spun off into Compass Group in 1987. Compass began with the goal becoming the world's largest foodservice corporation. Thereafter an ambitious plan of expansion began with the acquisition of railway caterers, airline catering, and Canteen Corp., the third largest vending and foodservice company in the U.S. in the early 1990s. By purchasing Eurest in 1995, Compass became the largest foodservice organization in the world in less than a decade (Grant, 2001a).

During the 1990s and into the 2000s Sodexo, ARAMARK, and Compass all increased consolidation and experienced "record expansion" (Grant, 2001a, p. 123). Sodexo moved into prison management, including foodservices, in the U.S., bought the largest British catering firm, and in 1998 bought the foodservice arm of Marriott (Grant, 2001b). Compass moved into new sites in Africa and purchased Brazil's largest caterer. The widespread growth and consolidation of food and agriculture TNCs during the last two decades (Clapp \& Fuchs, 2009) is exemplified by institutional foodservice corporations. Consolidation has contributed to efficiencies of scale and given foodservice TNCs the ability to negotiate advantageous procurement contracts. And expansion continues. Most recently, ARAMARK was the 2008 Beijing Olympics official caterer and proclaimed that this would provide access to China's "untapped" USD170 billion educational catering market (Tschang, 2008).

As government services were privatized, foodservice TNCs began to change the structure of labor in this industry. For example, the privatiza- 
tion of health support services in British Columbia, Canada, led to the elimination of 8,500 publicsector jobs, including foodservice workers, and it is reported that pay rates for the affected positions were cut by more than 40 percent (Stinson, Pollak, \& Cohen, 2005). The privatization of public services enabled impressive growth for the foodservice TNCs, but also shifted public resources away from foodservice workers and local suppliers.

Although the contemporary global foodservice industry is dominated by three foodservice TNCs, their marketing practices and branding strategies make them almost invisible to the consumer. Branding is used to differentiate between workplaces and institutions as well as seemingly to expand foodservice within single outlets. For instance, Compass uses product differentiation to leverage sales by creating brands for the different service sectors. In North America alone it operates Chartwells for education, Morrison for healthcare, Wolgang Puck Catering, Eurest for business, and Canteen Services for prisons. Often nested within these outlets, TNCs buy and operate franchises, such as Starbucks and Tim Horton's, side-by-side, which further expands the market in the same campus or hospital. At the same time as fostering the illusion of qualitative differences between cups of coffee, the corporations benefit from the economies of scale that come with centralized management of supplies and labor.

\section{Contemporary Issues}

Institutional food outlets are primarily located in public institutions such as hospitals, long-term care facilities, and the educational sector such as universities and colleges (Datamonitor, 2008) and these public institutions increasingly require revenue streams. Foodservice TNCs have developed foodservice models to increase sales and reduce costs in order to compete for contracts, and one of their main tools for reducing purchasing costs is to achieve economies of scale (Datamonitor, 2007). Foodservice contractors are also shifting away from the cafeteria model and now use multiple outlets and sophisticated branding and food production techniques to increase sales and reduce labor costs. Capital investments are part of longterm contracts and are used to increase market penetration by expanding outlets on campuses by adding, for example, convenience stores and coffee kiosks (Lawn, 2007). In addition, the model is reliant on cash rebates from large food manufacturers (FoodService Director, 2001), which dictate the kind of food that is purchased and offered for sale.

The largest cost area for foodservice is labor, and a great deal of energy is focused on reducing and controlling these costs. For example, major capital investments are used to replace laborintensive food production with convenience products such as frozen and preportioned meals, which only requires a worker to heat and serve (Creed, 2001). Foodservice TNCs also have sophisticated strategies to deal with unions in order to keep costs down, and the global reach and centralized nature of TNCs puts the dispersed union movement at a distinct disadvantage. For example, in Canada there are six different unions that negotiate with foodservice TNCs, and the companies often negotiate with the weakest unions first in order to depress wages (M. Luff, personal communication, December 13, 2007). Successful labor strategies are quickly deployed from one country to another. This situation is exacerbated by the fact that the sector employs marginalized communities that are particularly vulnerable, such as new immigrants who may not be aware of their rights at the workplace and international students on campuses (M. Luff, personal communication, December 13, 2007).

The privatization of government services opened up new markets for foodservice TNCs (King, 2000), which included foodservices in Canada. As services were outsourced, there was a loss of unionized public-sector jobs. While some of these employees have been hired by foodservice TNCs, few contracts have remained unionized (M. Luff, personal communication, December 13, 2007). No figures are available for union membership, but the institutional foodservice sector is reported to have one of the lowest union densities in comparison to other foodservice sectors $(M$. Luff, personal communication, December 13, 2007). Furthermore, in 2007 a new way of restructuring labor in Canada was initiated when Compass applied to bring workers into $\mathrm{BC}$ under the 
Temporary Foreign Worker Program because it claimed it could not find employees to work in the Vancouver Island Hospitals where it had a service contract (Hospital Employees' Union, 2007).

Consolidation of the TNCs has produced a highly concentrated institutional food sector; any new entrants to the sector are at a disadvantage because of the established economies of scale and supply chains, and most importantly, capital. Smaller operators routinely lose contracts because they are unable to offer the capital investments that are now part of contract negotiations (Elan, 2005). As a result of roll-backs in funding for education and health care, public institutions are now demanding more financial contributions. Longterm, multiyear foodservice contracts typically include terms of exclusivity and require extensive capital expenditures on the university infrastructure, such as new construction or improvements to existing foodservice facilities (Porter, 2006). These investments, however, are portrayed as added bonuses:

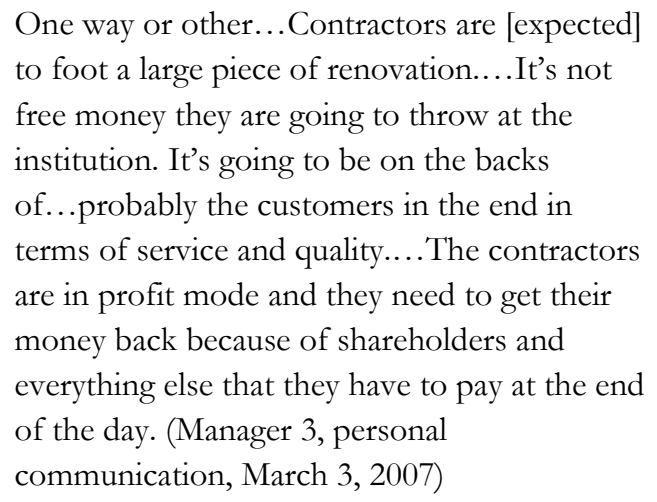

For example, Carleton University in Ottawa, Ontario, signed a new 10 year contract with ARAMARK in 2003 that included a CAD3.5 million investment in "facility upgrades." ARAMARK won one of the largest institutional food contracts in Canada (Chappell, 2003), and the university obtained capital improvements. In addition, the Carleton contract with ARAMARK also includes a minimum cash commission of $\$ 250,000$ annually, thereby providing a steady revenue stream to the university (Chappell, 2003).

As institutions look to foodservice for revenue, the squeeze on labor and food costs will continue.
During the Second World War, the state leveraged industrial feeding to "solve" industrial unrest and worker productivity. Today, institutional food helps to "solve" decreasing state revenue for education and health care. This raises questions about how local food system advocates can work with the institutional food sector.

\section{Opportunities for Change}

Despite the many challenges discussed above, there are also opportunities, and some institutional food provision is moving in a new direction. The literature on industry opportunity structures helps us understand why. It is useful to consider institutional food corporations in light of the four factors identified in our introduction as critical to an industry's willingness to shift in relation to a social movement organization's goals: interfirm competitiveness; the nature of the goods sold; corporate cultures; and relationships in the industry's organizational field (Schurman, 2004).

With regard to interfirm competitiveness, the above discussion shows how competition for contracts has pushed the main players in this field to lower costs above anything else. However, it is the very nature of the competition that has contributed to the success of the third-party Local Food Plus's intervention in the University of Toronto (U of T) contract. The $\mathrm{U}$ of $\mathrm{T}$ contract with its foodservice TNCs was a direct result of the university's sustainability policy, designed to ensure that the university foodservice outlets provide a minimum quantity of sustainably produced foods grown within $250 \mathrm{~km}$ (155 miles) of Toronto. LFP (2007) defines sustainability by a number of criteria, including the use of more environmentally friendly growing techniques, energy conservation, animal welfare, habitat protection, and on-farm labor standards. Since 2007, LFP products have also been picked up by a small supermarket chain, and demand continues to outstrip supply (Friedmann \& McNair, 2008). When the call for tenders (request for proposals, in U.S. parlance) stipulated that a certain percentage of the goods provided within a public institution must meet specific criteria, each of the three major players in this sector worked with Local Foods Plus and the university to submit bids (Friedmann, 2007). In other words, the 
extremely tight competition and profit-seeking strategies in this field mean that all three players are willing to change their purchasing practices when required by a call for tenders. ${ }^{2}$

One might expect that the standardization of goods sold by institutional food providers means there is little reason for them to adopt locally produced product. On the one hand, the companies do the branding or adopt well known national and international brands (in soft drinks, coffee, etc.), thus limiting opportunities for product differentiated by local origin. On the other hand, the fact that these companies have control over their supply chains means that they can decide to buy local product and then develop a brand for it. A similar strategy has been seen in the retail sector over the last 20 years. Previously, grocery stores in North America were filled with product branded by the food processors. More recently, however, and illustrating a general shift from processor to retailer power in the food system, the retailer has developed higher-end "house" brands based on undifferentiated inputs (Barndt, 2008). This same strategy of developing house brands has also been pursued by the institutional food providers, and may present an opportunity if pursued in partnership with (and thus dependent on) local suppliers, since many of the fresh food categories in which they would supply product are not already dominated (in the minds of the customers) by powerful national and international brands.

Corporate cultures represent a clear challenge to the local food movement, since such foods rarely fit in with the trend across all three of these companies toward lower costs, outsourced processing, and mass scale. Then there is the culture of scientifically defined 'good' food, which in the present era tends to be drawn on by companies to promote regulations (whether public or private) that are only suitable to larger rather than smallerscale processing (Schmidt, 2008). On the other hand, there is evidence that the attitudes of some consumers may be shifting toward preferring less processed foods, or those processed on a smaller scale as a result of the listeria, E. coli, and

${ }^{2}$ Clarification on this point was provided by an anonymous reviewer. salmonella outbreaks affecting larger processors that are increasingly in the news (Pollan, 2006, 2010; Taylor, 2008).

Furthermore, other cultures are also relevant here. One is the culture of the institutions where this food is sold. Universities, for example, are typically defined by progressive cultures, and these cultures are affecting policies on campuses that are commensurate with a shift toward local food provision. Take the anti-sweat shop movement, which has managed to get over 250 universities in North America to refuse to sell specific types of clothing (http://usas.org/). We have observed the rapid adoption of fair-trade coffees and teas in university cafeterias, supplied via the TNCs of interest here, as a result of growing awareness among consumers around these products. The University of Guelph also only sources free-range eggs, and other universities have also shifted their buying due to specific pressures. As one foodservice manager reported:

The reason we went to free-run eggs is because a group in BC [British Columbia]...was calling all of the directors of university services across Canada and said you should switch to free-run eggs for the humane treatment of chickens. If you don't you will come under scrutiny or negative publicity. You could watch the wave from one end of Canada to the other as every university began to switch over to free-run eggs regardless of costs, regardless of what students wanted. All these intelligent people simply switching for the pressure, rather than the reality of the situation. (Manager 2, personal communication, February 2, 2007)

Another manager acknowledged the effect of the campaigns and reported:

We have gone through the "killer Coke"3 issue, the whole caged egg [vs. free run] thing

\footnotetext{
3 The "Killer Coke" campaign to ban Coke from university campuses was launched in 2003 in reaction to the killings of Colombian workers at Coke bottling plants. A number of campuses did not renew their contracts with Coke due to the pressure (Foust, Smith, \& Woyke, 2006).
} 
program from students. (Manager 3, personal communication, March 3, 2007)

These examples show that the cultures of institutions do change, and foodservice providers have to go with these shifts if they wish to remain legitimate in the eyes of their primary customers.

Schurman and Munro (2009) point out that "national" cultures are also important here, meaning the larger sociocultural shifts within which institutions and institutional food providers are embedded. It is on this scale that the local food movement is having an impact on the context in which these TNCs do business, as witnessed by the myriad books and news articles written on this subject in recent years (e.g. Pollan, 2006; Smith \& MacKinnon, 2007). Institutional food providers appear to be paying heed to local and sustainable food movements' calls for change. ARAMARK, the Carleton University food provider noted above, now states on its website that among its "sustainability initiatives" (which include the introduction of biodegradable cutlery and limited composting) is a commitment to supporting local farmers and organic foods:

Dining Services is continuously working on
providing a sustainable environment and
constantly searching for local suppliers and
organic options. Being situated in a Canadian
environment where summer is not all year
round, local produce is not always available,
however when it is available to Dining Services
we do purchase and support local farmers. As
well we use organic food when it is available
and cost efficient to our customers. Currently
we do offer organic coffee and tea all year
round, as well as organic greens. (ARAMARK,
2010)

While this is a rather vague commitment, and is not tied to the type of contract that LFP has developed at the University of Toronto, it is a clear demonstration that ARAMARK Canada has this issue on its radar screen and recognizes that it needs to adjust to the times when practicable. Moving any further than that would likely require pressure from its main customers: students.
Another consideration is that the people who are often served in some of these public institutions, such as schoolchildren and hospital patients, are considered vulnerable in the eyes of society. This is reflected in the fact that schools and hospitals are often targets for reform such as school gardens, bans on junk food, or farm-toschool programs. This perception can be played upon by local food practitioners.

The final key variables in the industry opportunity structure are the relationships within the industry's organizational field. The supply chain dynamics noted above are relevant here. Logistics are also important, since centralization is closely associated with the efficiencies of scale that these companies currently achieve; the local food movement must ensure that it can point to midsized local alternatives able to fit within such a system. Most importantly for the purposes of this paper, however, are the relationships between these private companies and the public bodies that hire them to provide food in these institutions. As already noted, these public bodies are increasingly reliant on the contracts with foodservice companies to actually inject cash into the institutions to help support core services such as health and education. This means these institutions may be in a difficult position when asking for new forms of food provision that may increase expenses, and thus lower revenues for the institution. Still, the history of these institutional food providers shows several things very clearly. They have not remained static and they are adaptable to the priorities of the time. In addition, despite the trends of the neoliberal era, earlier periods show a strong connection between institutional food providers and public policy.

What does this mean for local food systems practitioners and social movement organizations? This history suggests that institutional food providers try to meet policy priorities, whether it is the war effort or local food procurement. Practitioners and social movement organizations can work strategically with institutions through the contract process and sustainability policies to bend foodservice contracts, and in turn, the TNCs themselves, toward procurement of local food. 


\section{Conclusions}

Public institutions are being pressured by social movement organizations to facilitate the scaling up of local food with the aim of furthering sustainable agriculture, health, and environmental goals. However, one of the biggest challenges to local food procurement is the structure of contracted catering companies who operate within public institutions. The institutional food sector can reshape whole supply chains, but their food production practices and corporate structures are resistant to local food procurement because of their reliance on corporate supply chains, centralized management, and the deskilling of labor with the introduction of prepared food. However, there are opportunities tied to the structure of these TNCs and their competitive dynamics. This paper has traced the history and political economy of the foodservice industry, and through the lens of the industry opportunity structure literature we highlight strategic opportunities for social movement organizations to generate further movement toward sustainable local food systems. In particular, we identify a long association between these companies and public-sector goals, and their location in institutions that are particularly vulnerable to social movement organizations' critiques and boycotts, such as universities and hospitals.

There is clearly a tension between calls for institutional food providers to procure local and sustainably produced foods and the foodservice TNCs' historically defined logic, especially the trends of the neoliberal period. When we define sustainability broadly, as Allen and her colleagues (1991) have, to mean participatory and socially just food systems that are a form of resistance to industrial agriculture, this tension becomes especially clear. The institutional foodservice model is, we have argued, the consummate representation of the neoliberal agri-industrial food economy. How then to reconcile the goals of local food movements with institutional foodservice and the TNCs that operate them?

On the one hand, much of the logic of foodservice TNCs seems incommensurable with the aims of local food proponents. For example, the use of sophisticated marketing by foodservice TNCs may lead to sustainability initiatives, such as local food, becoming part of a branding campaign (a form of greenwashing) rather than making substantive change in how foods are supplied. In addition, local farmers who come to depend on this market may be required to lower prices as foodservice TNCs operate to aggressively lower their own costs. As Freidberg (2007) has illustrated, farmers may be required to yield to TNC standards rather than large TNCs yielding and reconfiguring their operations to accommodate local foods.

On the other hand, there are initiatives of the type represented by LFP. This research concurs with Friedmann (2007) that third-party certifiers may be the best way forward to initiate institutional contracts and to protect local farmers from the pressures exacted by these companies. She specifically points out that the complex foodservice procurement systems may contribute to the traceability of local foods. However, whether third-party certifiers will be truly successful in this endeavor remains unclear. In addition, we think it is important to point out that, given the history of these companies, it is imperative that social-justice requirements related to the foodservice side of the local procurement chain be included within the standards of an organization like LFP. Following Patricia Allen, it is incumbent upon such standards to illuminate and correct the "current lack of foodsystem justice" (Allen, 2008, p. 158). For us, this includes workers in the institutional foodservice sector. Although there are social-justice provisions for both food producers and growers within the LFP framework implemented at the University of Toronto and other sites, there are no criteria related to supporting foodservice workers within the current framework.

This paper illustrates how institutional foodservice has changed over the last 70 years, aligning with, and being supported by, state priorities in different historical periods. Most recently, the state has shifted its role, and institutional foodservice is not viewed as a site of social welfare but rather as a site of revenue for the public institutions that contract out foodservices. As the neoliberal era produces new kinds of institutional arrangements, we can look to other industries defined by this era, such as the companies that produce and market genetically modified organisms (Andrée, 2007), and 
learn lessons from how social movement organization resistance has shaped those industries over time (Andrée, 2011; Schurman \& Munro, 2009). If industrial feeding represented an acute form of state intervention during the Second World War, what does the intervention by the local food movement represent, and how will its priorities shape institutional food provision as we move forward? Will the consolidated foodservice industry model even be able to adapt to the new state and public priorities in the twenty-first century? And how should we understand, at a theoretical level, the relations between state, industry, and civil society that these new shifts represent? Clearly, institutional foodservice remains an area ripe for further research.

\section{References}

Allen, P., Van Dusen, D., Lundy, J., \& Gliessman, S. (1991). Expanding the definition of sustainable agriculture (Sustainability in the balance, Issue Paper \#3). Retrieved from http://casfs.ucsc.edu/publications/ sustainability-in-the-balance/expanding-thedefinition-of-sustainable-agriculture

Allen, P. (2008). Mining for justice in the food system: Perceptions, practices, and possibilities. Agriculture and Human V alues, 25(2), 157-161. http://dx.doi.org/10.1007/s10460-008-9120-6

Andrée, P. (2007). Genetically modified diplomacy: The global politics of agricultural biotechnology and the environment. Vancouver: University of British Columbia Press.

Andrée, P. (2011). Civil society and the political economy of GMO failures in Canada: A neoGramscian analysis. Environmental Politics, 20(2), 173-191. http://dx.doi.org/10.1080/09644016.2011.551023

Andrée, P., Dibden, J., Higgins, V., \& Cocklin, C. (2010). Competitive productivism and Australia's Eemerging "alternative" agri-food networks: Producing for farmers' markets in Victoria and beyond. Australian Geographer, 41(3), 307-322. http://dx.doi.org/10.1080/00049182.2010.498038

ARAMARK. (2010). Carleton University Dining Services Sustainability Initiatives. Retrieved from http://www.campusdish.com/en-US/CA/ Carleton/Sustainability/
ARAMARK. (n.d.). History. Retrieved January 15, 2012, from http://www.aramark.com/ AboutARAMARK/History/

Bagdonis, J., Hinrichs, C. C., \& Schafft, K. A. (2009). The emergence and framing of farm-to-school initiatives: Civic engagement, health and local agriculture. Agriculture and Human Values, 26(1-2), 107-119. http://dx.doi.org/10.1007/s10460-008-9173-6

Barndt, D. (2008). Tangled routes: Women, work, and globalization on the tomato trail (2nd ed.). Lanham, Maryland: Rowman \& Littlefield.

Becker, B. (1960, September 30). Big success story: Nuts to soup. The New York Times, p. 35.

Business of Keeping Factory Workers Well Fed Is Booming. (1942, March 26).W all Street Journal, p. 1.

Chappell, K. (2003, April). Aramark replaces Chartwells as food services supplier — $\$ 3.5$ million in facility upgrades planned. Carleton Now. Retrieved from http://carletonnow.carleton.ca/april-2003/ aramark-replaces-chartwells-as-food-servicessupplier-3-5-million-in-facility-upgrades-planned/

Clapp, J., \& Fuchs, D. A. (Eds.). (2009). Corporate power in global agrifood governance. Cambridge, Massachusetts: MIT Press.

Creed, P. G. (2001). The potential of foodservice systems for satisfying consumer needs. Innovative Food Science \& Emerging Technologies, 2(3), 219-227. http://dx.doi.org/10.1016/S1466-8564(01)00034-0

Curtis-Bennett, N. (1949). The food of the people: Being the bistory of industrial feeding. London: Faber and Faber.

Datamonitor. (2007). Canada - Cost foodservice Competitive Landscape. Retrieved from http://factiva.com

Datamonitor. (2008). Foodservice industry profile: Canada. (p. 1). Retrieved from http://ebscohost.com

Datamonitor. (2009). Foodservice industry profile: Global. (p. 1). Retrieved from http://ebscohost.com

Dominion Bureau of Statistics. (1944). Food consumption in Canada, 1944 and 1945. Ottawa: Author.

Dupertuis, Y. M., Kossovsky, M. P., Kyle, U. G., Raguso, C. A., Genton, L., \& Pichard, C. (2003). Food intake in 1707 hospitalised patients: A prospective comprehensive hospital survey. Clinical Nutrition, 22(2), 115-123. http://dx.doi.org/10.1054/clnu.2002.0623 
Edible Strategies Enterprises. (2007). Contending with the local food access puzzle: Final project report to the BC Medical Services Foundation. Nanaimo, British Columbia: BC Medical Services Foundation. Available at http://www.ediblestrategies.com

Edwards, J. S. A., Williams, P., Hartwell, H. J., \& Schafheitle, J. (2009). Comments on prison foodservice: England vs. Australia. Journal of Foodservice, 20(4), 153-156. http://dx.doi.org/10.1111/j.17480159.2009.00142.x

Egbers, A., \& Canadian Co-operative Association. (2009). The lay of the land: Local food initiatives in Canada. Ottawa, Ontario: Canadian Co-operative Association. Retrieved from Canadian Co-operative Association website: http://www.coopscanada. coop/public html/assets/firefly/files/files/ The Lay of the Land Final June 16 2009.pdf

Elan, E. (2005). Regional players gird for on-site onslaught. Nation's Restaurant News, 39(47), 47-50.

Équiterre. (2010). equiterre.org - For socially and environmentally responsible choices. Retrieved January 15, 2012, from http://www.equiterre.org/en

Feeding at Plants Cuts Absenteeism: Head of WF Plan for Industry Tells Chicago Technologists 12,500,000 Will Benefit. (1944, May 31). New York Times, p. 16.

FoodService Director. (2001). New items on the way: College rebates growing. FoodService Director, 14(1), 22.

Fortune. (2011). Global 500, 2011: Top Companies: Biggest Employers. Fortune. Retrieved from http://money.cnn.com/magazines/fortune/global 500/2011/performers/companies/biggest/

Foust, D., Smith, G., \& Woyke, E. (2006, January 23). "Killer Coke" or Innocent Abroad? BusinessWeek, (3968), 46-48.

Freidberg, S. (2007). Supermarkets and imperial knowledge. Cultural Geographies, 14(3), 321-342. http://dx.doi.org/10.1177/1474474007078203

Friedmann, H. (2007). Scaling up: Bringing public institutions and food service corporations into the project for a local, sustainable food system in Ontario. Agriculture and Human Values, 24(3), 389398. http://dx.doi.org/10.1007/s10460-006-9040-2
Friedmann, H., \& McNair, A. (2008). Whose rules rule? Contested projects to certify "local production for distant consumers." Journal of Agrarian Change, 8(23), 408-434. http://dx.doi.org/10.1111/j.14710366.2008.00175.x

Goodhart, R. (1943). Wartime feeding of industrial workers. Annals of the American Academy of Political and Social Science, 225, 116-121. http://dx.doi.org/10.1177/000271624322500141

Goodhart, R. S., \& Pett, L. B. (1945). The war-time nutrition programs for workers in the United States and Canada. The Milbank Memorial Fund Quarterly, 23(2), 161-179. http://dx.doi.org/10.2307/3348248

Goodman, D. (2003). The quality "turn" and alternative food practices: Reflections and agenda. Journal of Rural Studies, 19(1), 1-7. http://dx.doi.org/10.1016/S0743-0167(02)00043-8

Grant, T. (2001a). Compass Group. International Directory of Company Histories. (Vol. 23, pp. 121-124). Detroit, Michigan: St. James Press.

Grant, T. (2001b). Sodexho Alliance. International Directory of Company Histories. (Vol. 29, p. 442-444). Detroit, Michigan: St. James Press.

Grant, T. (Ed.). (2001c). ARAMARK Corporation. International Directory of Company Histories. (Vol. 41, pp. 21-24). Detroit, Michigan: St. James Press.

Hobsbawm, E. J. (1994). Age of extremes: The short twentieth century, 1914-1991. London: Joseph.

Hospital Employees' Union. (2007, October 11). Hospital contractor's plan to hire overseas workers points to Bill 29 privatization failure (News release). Retrieved from http://www.heu.org/newsmedia/news-releases/hospital-contractors-planhire-overseas-workers-points-bill-29-privatizatio

Industrial Feeding Held Vital in War: A Major Weapon. (1944, May 27). New York Times, p.18..

Izumi, B. T., Wright, D. W., \& Hamm, M. W. (2010). Farm to school programs: Exploring the role of regionally-based food distributors in alternative agrifood networks. Agriculture and Human Values, 27(3), 335-350. http://dx.doi.org/10.1007/s10460-009-9221-x

King, P. (2000). U.S. contractors eye Canadian industry's vast self-op sector. Nation's Restaurant News, 34(3), 45-47. 
Lawn, J. (2007, February). Taking measure of the market. Foodservice Management, 43-62.

Local Food Plus. (n.d.). About LFP | Local Food Plus. Retrieved January 15, 2012, from http://www.localfoodplus.ca/about

Mériot, S.-A. (2006). Nostalgic cooks: Another French paradox. Leiden and Boston: Brill.

Mikkelsen, B. E., Kristensen, N. H., \& Nielsen, T. (2005). Innovation processes in large-scale public foodservice-Case findings from the implementation of organic foods in a Danish county. Journal of Foodservice Business Research, 8(2), 87-105. http://dx.doi.org/10.1300/J369v08n02 07

Morgan, K., \& Sonnino, R. (2007). Empowering consumers: The creative procurement of school meals in Italy and the UK. International Journal of Consumer Studies, 31(1), 19-25. http://dx.doi.org/10.1111/j.14706431.2006.00552.x

Peck, J., \& Tickell, A. (2002). Neoliberalizing space. Antipode, 34(3), 380-404. http://dx.doi.org/10.1111/1467-8330.00247

Polanyi, K. (2001 [1944]). The great transformation: The political and economic origins of our time. Boston, Massachusetts: Beacon Press.

Pollan, M. (2006). The omnivore's dilemma: A natural bistory of four meals. New York: Penguin Press.

Pollan, M. (2010, June 10). The food movement, rising. New York Review of Books. Retrieved from http://www.nybooks.com/articles/archives/2010/ jun/10/food-movement-rising

Porter, D. (2006). Self-op vs. contract: What's right for your campus? Food Management, 41(11), 32-34.

Raynolds, L. T. (2000). Re-embedding global agriculture: The international organic and fair trade movements. Agriculture and Human Values, 17(3), 297-309. http://dx.doi.org/10.1023/A:1007608805843

Reconverted Industry to Continue Wartime In-Plant Feeding System. (1945, August 12). The New York Times, p. S5.

Renting, H., Marsden, T. K., \& Banks, J. (2003). Understanding alternative food networks: Exploring the role of short food supply chains in rural development. Environment and Planning $A$, 35(3), 393-411. http://dx.doi.org/10.1068/a3510
Ritzer, G. (1998). The McDonaldization thesis: Explorations and extensions. London: SAGE Publications.

Roosevelt Plans to Cut Living Cost; Wage "Lid" Stands: Price Slash Is Aim President Will Ask Funds from Congress for His Five-Point Program. (1943, July 24). The New York Times, p. 1.

Schmidt, S. (2008, October 10). Maple Leaf CEO complains of inspection double standards. Canada.com. Retrieved from http://www.canada. $\mathrm{com} /$ topics/news/national/story.html?id= 4c6f2019-2f68-4d7b-bce0-be71aca8dc84

Schurman, R. (2004). Fighting "Frankenfoods": Industry opportunity structures and the efficacy of the antibiotech movement in Western Europe. Social Problems, 51(2), 243-268. http://dx.doi.org/10.1525/sp.2004.51.2.243

Schurman, R., \& Munro, W. (2009). Targeting capital: A cultural economy approach to understanding the efficacy of two anti-genetic engineering movements. American Journal of Sociology, 115(1), 155-202. http://dx.doi.org/10.1086/597795

Scrinis, G. (2008). On the ideology of nutritionism. Gastronomica, 8(1), 39-48. http://dx.doi.org/10.1525/gfc.2008.8.1.39

Seyfang, G. (2006). Ecological citizenship and sustainable consumption: Examining local organic food networks. Journal of Rural Studies, 22(4), 383-395. http://dx.doi.org/10.1016/j.jrurstud.2006.01.003

Smith, A., \& MacKinnon, J. B. (2007). The 100-mile diet: A year of local eating. Toronto: Random House Canada.

Sonnino, R. (2007). Embeddedness in action: Saffron and the making of the local in southern Tuscany. Agriculture and Human Values, 24(1), 61-74. http://dx.doi.org/10.1007/s10460-006-9036-y

Stinson, J., Pollak, N., \& Cohen, M. (2005). The pains of privatization: How contracting out hurts health support workers, their families, and health care. Canadian Centre for Policy Alternatives, British Columbia Office.

Sustain UK. (2009). Good food on the public plate: What we have done and what we have learned. London, UK: Sustain: The alliance for better food and farming. Retrieved from http://www.sustainweb.org/ publications $/$ ?id $=175$ 
Sustain UK. (2012). Good Food on the Public Plate. Retrieved January 15, 2012, from http://www.sustainweb.org/goodfoodpublicplate

Taylor, D. A. (2008). Does one size fit all?: Small farms and U.S. meat regulations. Environmental Health Perspectives, 116(12), A529-A531. http://dx.doi.org/10.1289/ehp.116-a528

Tschang, C.-C. (2008, April 9). Aramark preps for Olympic feeding frenzy. BusinessW eek Online, 21.

U.S. Buying Meat for War Plant Use: Shortage Forces Agriculture Bureau to Supply Lamb to Coast Cafeterias. (1945, July 24). The New York Times, p. 24.
Vogt, R., \& Kaiser, L. (2008). Still a time to act: A review of institutional marketing of regionallygrown food. Agriculture and Human V alues, 25(2), 241-255. http://dx.doi.org/10.1007/s10460-007-9106-9

Winson, A. (1992). The intimate commodity: Food and the development of the agro-industrial complex in Canada. Toronto: Garamond Press.

Yigit, V., Tengilimoglu, D., Kisa, A., \& Younis, M. Z. (2007). Outsourcing and its implications for hospital organizations in Turkey. Journal of Health Care Finance, 33(4), 86-92. 